\title{
Effect of Organic Manure on Growth and Yield of Transplanted Rice (Oryza sativa L.) under Coastal Cauvery Deltaic Region
}

\author{
N. Sathiyabama ${ }^{1 *}$, L. Aruna ${ }^{1}$, K.Illakia ${ }^{1}$, C. Dhayanithi ${ }^{2}$, V. S. V. G. Naresh ${ }^{1}$, \\ R. Jayaraghavi ${ }^{1}$ and V. R. Mageshen ${ }^{1}$ \\ ${ }^{1}$ Department of Soil Science and Agricultural Chemistry, Pandit Jawaharlal Nehru College of \\ Agriculture and Research Institute, Karaikal-609603, Puducherry, India \\ ${ }^{2}$ Annamalai University, Chidambaram-608002, Tamil Nadu, India \\ *Corresponding author
}

Keywords

organics, Green

manure, Green leaf

manure,

Vermicompost,

Daincha

Article Info

Accepted:

25 May 2021

Available Online:

10 June 2021

\section{A B S T R A C T}

A field experiment was conducted at Pandit Jawaharlal Nehru College of Agriculture and Research Institute, Karaikal in order to study the Effect of Organic Manure on Growth and Yield of Transplanted Rice (Oryza sativa L.) under Coastal Cauvery Deltaic Region. The present study was made to evaluate the extent of contribution of added organics viz. green manures (Daincha, Sunhemp) and green leaf manures (Pungam and Glyricidia) with different levels of vermicompost $\left(0,1,2 \mathrm{t} \mathrm{ha}^{-1}\right)$ and their effect on transplanted rice growth and yield parameters. The application of green manure, Daincha significantly produced taller plants and higher LAI at all the growth stages, while on contrary, the GM/ GLM and vermicompost did not favor the number of tillers per $\mathrm{m}^{-2}$ and DMP conspicuously. Organic manure treatments significantly enhanced the number of productive tillers, No. of grains panicle ${ }^{-1}$, spikelet fertility and panicle weight when compared to the control. At the same time, better performance of vermicompost @ 1 or $2 \mathrm{t} \mathrm{ha}^{-1}$ in increasing the number of spikelets panicle ${ }^{-1}$ and filled grains panicle ${ }^{-1}$ had been observed. Among the GM/ GLM, the application of Daincha edged over the other GM/GLM treatments and produced significantly higher grain yield.

\section{Introduction}

Rice (Oryza sativa L.) is the most important and extensively cultivated food crop, which provides half the daily food for one out of every three persons on the earth. In Asia alone, more than two billion people obtain 60 to 70 per cent of their energy intake from rice and its derivatives. The agriculture of the modem chemical era concentrates on maximum output but overlooks input efficiency because of which it has not been sustainable (Ladha et al., 1995). As a result, the soil is mined out of nutrients. Production of quality food grains in sufficient quantity forever growing population without damaging the soil quality, fertility and productivity of soil is one of the major challenges in the 
present agriculture scenario. Among the organic sources the green manure crops and vermicompost are provide a good amount of organic matter, plant nutrients and it contribute to the soil nutrient dynamics to restore the soil health. Most studies describe the effect of inorganic alone or combination of organic and inorganic fertilizer under various rates of substitution usually not exceeding 50 per cent of inorganic nutrient level. However, the effect of complete exclusion of inorganic nutrient sources in rice nutrition needs to be studied to make meaningful recommendation on organic nutrient management for rice-based cropping sequence. Considering the importance of the above aspects, field study was carried out to study the effect of organic manures on growth and yield of organic rice.

\section{Materials and Methods}

The field experiment was conducted during Rabi season (August 2018 to March 2019). The college farm is located $12 \mathrm{~km}$ away from the karaikal seashore of Bay of Bengal. The experimental site is situated on a plain topography at $10^{\circ} 55^{\prime} \mathrm{N}$ latitude and $79^{\circ} 49^{\prime} \mathrm{E}$ longitude at an altitude of four meters above the mean sea level. Karaikal region comes under eleventh agro-ecological zone of India and it is classified as $\mathrm{PC}_{2}$ coastal deltaic alluvial plain zone. Karaikal has a tropical climate with the mean maximum and minimum temperature of 33 and $24{ }^{0} \mathrm{C}$ respectively.

The mean annual rainfall is $1374 \mathrm{~mm}$. The normal maximum and minimum temperature during the cropping period (August to March) were 32.04 and $23.68^{\circ} \mathrm{C}$, respectively. The normal rainfall during cropping season is $1018.1 \mathrm{~mm}$. The soil of the experimental field was sandy loam in texture, and it belongs to Sorakudy soil series of Fluventichaplusteps. The initial soil was neutral in reaction with a $\mathrm{pH}$ of 6.89 and non-saline with an EC of 0.166
$\mathrm{dSm}^{-1}$. The fertility status of the soil was low in available $\mathrm{N}$, low in available phosphorus and medium in available potassium.

The experiment was conducted with two factors one with green manures (Daincha, Sunhemp) and green leaf manures (Pungam and Glyricidia) and another at three levels (0, $1,2 \mathrm{t} \mathrm{ha}^{-1}$ ) of vermicompost in a Randomized Block Design (RBD) with an absolute control and replicated thrice.

The green manure crops were grown in the respective treatment plots and were incorporated after taking weights, while equivalent quantity of green leaf manures was brought elsewhere from the farm and incorporated in the respective plots.

Separate wet nursery was prepared, and pregerminated ADT(R) 46 seeds were sown. The 25 days old seedlings were transplanted in the treatment plots.

In each treatment plots, five hills were randomly selected and tagged for taking biometric observations. The growth parameters plant height, number of tillers, leaf area index (LAI) were recorded from the tagged hills at active tillering (60 DAS), panicle initiation (75 DAS), flowering (90 DAS) and at harvest stages of crop.

The plants outside the net plots were harvested and thrashed separately. After completion of the border row harvesting in each plot, the plants within the net plot area was harvested and thrashed to separate grains.

The grains thus obtained were cleaned, sun dried to bring the grain moisture to 14 per cent. The grain weight was then obtained to express the grain yield in $\mathrm{kg} \mathrm{ha}^{-1}$. The straw obtained after separation of grains from each plot was sun dried and the dry weight was recorded to express the straw yield in $\mathrm{kg} \mathrm{ha}^{-1}$. 
The harvest index was calculated using the formula as follows:

Harvest index

Economic yield $\left(\mathrm{kg} \mathrm{ha}^{-1}\right)$

Biological yield $\left(\mathrm{kg} \mathrm{ha}^{-1}\right)$

\section{Statistical Analysis}

The biometric observations, yield parameters, yield and laboratory analytical data obtained during investigation were subjected to statistical scrutiny by following the procedures outlined by Rangaswamy (2016).

\section{Results and Discussion}

\section{Growth parameters of rice}

Organic farming may be an important strategy for sustainable production of crops. This may not only improve the soil health but increases soil microbes, crop yield and improves available major and minor nutrients (Rautaray et al., 2003).

The growth of the plant is observed through plant height, number of tillers plant ${ }^{-1}$, leaf area index (LAI) and dry matter production (DMP). Growth characters can be altered by crop management practices.

In most of the cases, the plant growth and development process were regulated by various nutrient management practices. Green manuring is one of the important factors, which is directly influencing the plant by changing the ability of the plant to respond to the availability of nutrients. In the present study, growth characters were distinctly influenced by different source of green manures applied in the experimental plot, which have been elucidated through plant height, number of tillers plant ${ }^{-1}$, LAI and dry matter production of rice.

\section{Plant height}

There exists a significant variation between the control and organic manure treatments at all the growth stages of the rice crop. The mean plant height of rice averaged across organic manure treatments was significantly taller (57.2, 82.6, 106.7 and $106.6 \mathrm{cms}$ during AT, PI, F and at harvest stages, respectively) than the absolute control (45.6, 69.2, 95.7 and $95.1 \mathrm{cms}$ during AT, PI, F and at harvest stages, respectively).

Among the green manures and green leaf manures, the green manure treatment found to increase the plant height of rice at all stages, when compared to green leaf manures. Daincha registered its superiority by registering significantly taller plants at all crop growth stages $(59.2,86.9,111.2$, and 111.1 cms during AT, PI, F and at harvest stages, respectively) when compared to all other green manure treatments. However, pungam at active tillering and panicle initiation, pungam and glyricidia at flowering and at harvest stages were statistically similar in registering on par and significantly shorter plants. Among the green manures, Daincha produced the tallest plant which might be due to higher decomposable biomass addition, enhanced mineralization and improved the availability of nutrients in the rhizo-ecosystem of the soil. The lower height of rice plant was observed in Pungam at all crop growth stages which might be due to their unsynchronized and slower decomposition owing to higher lignin to $\mathrm{N}$ ratio even though they consist of higher $\mathrm{N}$ content.

\section{Number of tillers $\mathbf{m}^{-2}$}

The absolute control treatment registered significantly lower number of tillers $\mathrm{m}^{-2}$ at all the growth stages $(359.6,369.6,346.3$ and 313.0 during AT, PI, F and at harvest stages, respectively) while the organic treatments 
averaged across GM/ GLM and vermicompost levels had produced significantly higher number of tillers $\mathrm{m}^{-2}$ (572.7, 569.4, 469.5 and 436.2 during AT, PI, F and at harvest stages, respectively).

On the other hand, neither the GM/ GLM nor vermicompost levels individually or their interactions had influenced significantly the number of tillers $\mathrm{m}^{-2}$ at any of the growth stages.

Tillering is related with genetic behavior of a variety but widely altered by soil aeration, spacing and soil nutrient supply. Tillering is the outcome of expansion of auxillary buds which is closely associated with nutritional condition of mother culm during early growth period and gets improved by supply of N. This increase in number of tillers $\mathrm{m}^{-2}$ with applied organics would have concluded the availability of nutrients especially $\mathrm{N}$ in the soil.

\section{Leaf Area Index}

The LAI gradually increased from AT to flowering stage in all the treatments. There exists significant variation in LAI at all the growth stages between organic treatments and absolute control. Similarly, there exists significant variation between GM/ GLM in registering LAI, whereas, the vermicompost levels remain non-significant at all the growth stages.

The control treatment registered significantly lower LAI (1.6, 2.4 and 2.7 during AT, PI and $\mathrm{F}$ stages, respectively) while the organic treatments registered significantly higher LAI of 3.6, 4.4 and 4.9 during AT, PI and F stages, respectively. Among the GM/GLM treatments, Daincha (4.6) and sunhemp (3.6) during active tillering and Daincha alone (5.1 and 5.8 during PI and F stages, respectively) at the rest of the growth stages recorded significantly higher LAI. Pungam and glyricidia at active tillering stage (3.0 and 3.2, respectively) and all GM/ GLM except Daincha during rest of the stages registered statistically similar LAI. The interaction effect of green manure and vermicompost levels didn't show any significant variation on LAI of rice in all the growth stages.

In case of plants, leaves are important and have an active role in photosynthesis. Optimum leaf area is important to obtain high yield. The LAI increases with increasing level of nutrient application. The better manipulation of nutrient availability in soil will result in optimum LAI for better photosynthesis, increased DMP thereby resulting in higher crop yield.

In the present investigation, increased leaf area index was observed with Daincha at all stages of crop growth. The higher leaf area index might be due to taller plants with more number of tillers $\mathrm{m}^{-2}$, leaf number, leaf length and breadth. The increase in leaf area index could help the crop to get more assimilating area available.

\section{DMP (kg ha $\left.{ }^{-1}\right)$}

There was a steep increase in DMP from AT to panicle initiation and then to flowering stages. However, none of the treatments had produced significant variation in DMP of rice at all the growth stages except panicle initiation and flowering stages. At both the stages, there exists significant variation between absolute control and organic treatments, while within the GM/ GLM and vermicompost levels, there exists nonsignificant variation in DMP. At active tillering stage, organic treatment $\left(1426 \mathrm{~kg} \mathrm{ha}^{-}\right.$ $\left.{ }^{1}\right)$ and Absolute control (1306 kg ha ${ }^{-1}$ ) were statistically equal, however, at later growth stages, organic treatments averaged across 
GM/GLM and vermicompost levels (6377 and $11008 \mathrm{~kg} \mathrm{ha}{ }^{-1}$ during PI and F stages, respectively) were significantly higher than the control (2361 and $6088 \mathrm{~kg} \mathrm{ha}^{-1}$ during PI and $\mathrm{F}$ stages, respectively).

Dry matter accumulation is the cumulative effect of individual plant parameters and reliable index of crop growth. The DMP increased steadily with the advancement of crop growth. The DMP significantly increased at all stages due to application of organics when compared to control.

The probable reason might be attributed to the continuous slow release of nutrients from added GM/GLM with or without vermicompost. Even though, individually few GM/ GLM treatments had favoured the growth parameters of rice, on a cumulative index such as DMP, all the GM/ GLM and vermicompost levels had performed statistically equal, since the nutrition to crop might have been released in statistically equal quantity but at slightly different time. The results are similar to the findings of Roy et al., (2006). The lower value of DMP was observed in the control plot but was significantly lower only during flowering stage when compared to manured plots. The reason for the poor performance of the control in flowering might be due to poor inherent capacity of soil to supply nutrients to meet out the crop demand at later stages.

\section{Yield parameters of rice}

Yield contributing characters such as number of productive tiller $\mathrm{m}^{-2}$, panicle length, panicle weight, spikelet fertility and test weight were not influenced by the application of GM/GLM with and without vermicompost.

In the present study, organic manure applied treatments significantly enhanced the number of productive tillers, number of grains per panicle, spikelet fertility and panicle weight when compared to the control plot. The advantage of organic manure is obvious, as it provides a steady and synchronized supply of nutrients leading to better growth of plants and might have contributed to enhanced yield attributes. The result is also in agreement with the findings of Sharma et al., (2006). The increase might also due to the balanced supply of nutrients from green manures, green leaf manure and vermicompost which enhanced the yield attributes

Better performance of vermicompost levels irrespective of GM/GLM treatments in increasing the number of spikelets per panicle at vermicompost @ $2 \mathrm{t} \mathrm{ha}^{-1}$ and filled grains per panicle at both vermicompost levels @ 1 and $2 \mathrm{t} \mathrm{ha}^{-1}$ had enlightened the sustained release of nutrients throughout the crop growth period by the GM/ GLM + vermicompost rather than applying alone. The slow release of nutrients throughout the crop growth thus helping to form more photosynthates and translocating the same from source to sink. The immediate release of $\mathrm{N}$ due to improved soil physical properties by the application of vermicompost would have enhanced the crop growth and in turn yield attributes of rice.

In contrast, the above yield components were greatly reduced in control plot mainly due to unavailability of required quantity of nutrients which was in confirmation with earlier finding of Ali et al., (1993).

\section{Number of productive tillers $\mathbf{m}^{-2}$}

The number of productive tillers $\mathrm{m}^{-2}$ did not show any significant variation between GM/ GLM treatments or between vermicompost levels. However, the absolute control treatment registered significantly lower number of productive tillers $\mathrm{m}^{-2}$ (306.4) while the organic treatments averaged across GM/ 
GLM and vermicompost levels had registered significantly higher number of productive tillers $\mathrm{m}^{-2}$ (429.6).

\section{Number of spikelets panicle ${ }^{-1}$}

The GM/ GLM treatments had not produced significant variation on the number of spikelets panicle $^{-1}$, while the vermicompost levels registered significant influence on the number of spikelets panicle ${ }^{-1}$. Among the levels of vermicompost used in the study, vermicompost @2 $\mathrm{t} \mathrm{ha}{ }^{-1}$ had produced significantly higher number of spikelets panicle $^{-1}$ (127) whereas, the no vermicompost and vermicompost @ $1 \mathrm{t} \mathrm{ha}^{-1}$ was significantly on par and lower (111 and 114 in no vermicompost and vermicompost @ $1 \mathrm{t} \mathrm{ha}^{-1}$, respectively).

The interaction effect of green manure and vermicompost didn't show any marked variation on the number of spikelets panicle ${ }^{-1}$. Similarly, the absolute control (102) and organic treatments averaged across GM/ GLM and vermicompost (118) also remained non significant in recording number of spikelets panicle $^{-1}$.

\section{Number of filled grains panicle ${ }^{-1}$}

The absolute control without organic manure addition (93.8) had registered significantly lower number of filled grains panicle ${ }^{-1}$, while at the same time the organic manure treatment averaged across GM/ GLM and vermicompost had recorded statistically higher number of filled grains panicle ${ }^{-1}(100.3)$.

In contrast to response of rice to organic manure treatments with respect to other parameters, the GM/ GLM remained nonsignificant, while the vermicompost levels registered significant variation on number of filled grains panicle ${ }^{-1}$. The vermicompost levels@1 and 2 t ha ${ }^{-1}$ had produced significantly greater number of filled grains panicle $^{-1}$ (106.6 and 113.7 in vermicompost @ 1 and $2 \mathrm{t} \mathrm{ha}^{-1}$, respectively) than the respective control without vermicompost (99.4).

\section{Grain yield $\left(\mathrm{kg} \mathrm{ha}^{-1}\right)$}

The absolute control treatment without any additional nutrient sources had registered significantly the lowest grain yield of $2450 \mathrm{~kg}$ $\mathrm{ha}^{-1}$, whereas the organic treatments averaged across GM/ GLM and vermicompost had significantly recorded higher grain yield of $3246 \mathrm{~kg} \mathrm{ha}^{-1}$.

Among the organic manure treatments, there exists significant variation only between the GM/ GLM treatments, while the vermicompost levels remained non-significant in their response. Among the GM/ GLM, Daincha had registered significantly the highest grain yield of $3707 \mathrm{~kg} \mathrm{ha}^{-1}$. The other GM/ GLM had registered significantly on par and lower grain yield (3203, 3029 and 3043 $\mathrm{kg} \mathrm{ha}^{-1}$ by Sunhemp, Pungam and Glyricidia, respectively).

In physiological term, yield of most cereals are largely governed by source (photosynthesis) and sink (grain formation) relationship. However, capacity of the system to transport the photosynthates and partitioning of assimilates between their sites of utilization is the major determinants of crop yield.

Among the GM/ GLM, the application of Daincha significantly registered higher grain yield as compared to other GM/GLM treatments (Fig. 1). The beneficial effect of producing higher grain yield with Daincha might be due to synchronized decomposition and mineralization that might have fulfilled the demand of nutrients in more balanced manner which aided in better growth and yield attributes. The synchronized decomposition 
and mineralization might again be due to their low $\mathrm{C}: \mathrm{N}$ ratio, low lignin: $\mathrm{N}$ ratio and their succulent nature as is a easily degradable leguminous green manure. Similar results have been reported by Lourduraj (2005) and Amanullah (2016).

The presence of beneficial and effective microorganisms predominantly bacteria, actinomycetes, yeast, certain fungi besides beneficial photosynthetic bacteria detected in added organics decomposition process, might have increased the crop growth and yield in organically manured treatments when compared to control plot.

\section{Straw yield and Harvest Index}

The absolute control treatment without any additional nutrient sources had registered significantly the lowest straw yield of $6560 \mathrm{~kg}$ $\mathrm{ha}^{-1}$, whereas the organic treatments averaged across GM/ GLM and vermicompost had significantly recorded $8555 \mathrm{~kg} \mathrm{ha}^{-1}$.

Unlike grain yield, none of the organic manure treatments viz., GM/ GLM and vermicompost levels either individually or their interactions had produced significant variations in the straw yield of organic rice

There exists significant difference only between absolute control and the organic treatments. On the other hand, none of the organic manure treatments viz., GM/ GLM and Vermicompost levels either individually or their interactions had produced significant variations on the harvest index. The absolute control registered significantly lower harvest index (0.32), while the organic treatments averaged across GM/ GLM and vermicompost treatments registered higher HI of 0.38. Straw yield of crop is closely related to vegetative growth namely plant height, no. of tillers, LAI and DMP of a crop. The beneficial effect of any treatment on any one or more of the above growth characters results in increased straw yield.

Though the straw yield and harvest index parameters had not varied between the GM/ GLM and vermicompost levels, the increase in straw yield and harvest index in the treatments averaged across organics treatments when compared with control (Fig. 1) was conspicuously noticed. It might be due to the fact that the enhanced and continuous supply of nutrients by organics would lead to better growth of the plant in terms of plant height, number of tillers, LAI and DMP. This is in accordance with the results obtained by Mohandas et al., (2008) and Oyekanmi et al., (2009).

The application of green manures namely Daincha significantly produced taller plants at active tillering, panicle initiation, flowering and at harvest stages when compared to other GM/GLM viz., Sunhemp, Pungam and Glyricidia. Similarly, the organic manure treatments registered significantly taller plants when compared to absolute control.

On contrary to plant height, the GM/ GLM and vermicompost did not favor the number of tillers per $\mathrm{m}^{-2}$ conspicuously but they register significantly higher tiller number when compared to control. In the present investigation, Daincha when compared to other GM/ GLM at all stages of crop growth and organic treatment when compared to control registered significantly higher LAI.

Organic manure treatments significantly enhanced the number of productive tillers, No. of grains panicle ${ }^{-1}$, spikelet fertility and panicle weight when compared to the control.

From the above, it could be concluded that Daincha was found to be the suitable green manure for rice crop shall be advocated to organic rice as it resulted in higher production. 
Table.1 Plant height (cms) of organically grown rice as influenced by GM/GLM with and without vermicompost.

\begin{tabular}{|c|c|c|c|c|c|c|c|c|c|c|c|c|c|c|c|c|}
\hline \multirow[t]{2}{*}{ Treatments } & \multicolumn{4}{|c|}{ Active tillering } & \multicolumn{4}{|c|}{ Panicle initiation } & \multicolumn{4}{|c|}{ Flowering } & \multicolumn{4}{|c|}{ Harvesting } \\
\hline & $\mathbf{V}_{0}$ & $V_{1}$ & $\mathbf{V}_{2}$ & $\begin{array}{c}\text { Mea } \\
n\end{array}$ & $\mathbf{V}_{0}$ & $\mathbf{V}_{1}$ & $\mathbf{V}_{2}$ & $\begin{array}{c}\text { Mea } \\
n\end{array}$ & $\mathbf{V}_{0}$ & $\mathbf{V}_{1}$ & $\mathbf{V}_{2}$ & $\begin{array}{c}\text { Mea } \\
n\end{array}$ & $\mathbf{V}_{\mathbf{0}}$ & $\mathbf{V}_{1}$ & $\mathbf{V}_{2}$ & $\begin{array}{c}M e a \\
n\end{array}$ \\
\hline $\mathbf{G}_{1}$-Daincha & 50.5 & 59.2 & 59.8 & 59.2 & 88.7 & 88.2 & 85.5 & 86.9 & 112.7 & 111.0 & 110.0 & 111.2 & 112.6 & 111.3 & 109.3 & 111.1 \\
\hline $\mathbf{G}_{2}$-Sunnhemp & 58.7 & 55.6 & 58.4 & 57.6 & 83.3 & 80.3 & 84.8 & 83.0 & 106.8 & 104.7 & 108.4 & 106.7 & 105.9 & 104.5 & 108.4 & 106.3 \\
\hline G3- Pungam & 54.6 & 56.0 & 55.3 & 55.3 & 79.3 & 78.7 & 78.4 & 78.8 & 104.3 & 102.6 & 103.9 & 103.6 & 105.9 & 104.5 & 104.4 & 104.0 \\
\hline $\mathbf{G}_{4}$-Gliricidia & 56.1 & 57.8 & 56.8 & 56.9 & 81.6 & 82.8 & 81.5 & 82.0 & 104.3 & 107.0 & 104.7 & 105.3 & 103.2 & 106.3 & 104.9 & 104.9 \\
\hline Treatment mean & 57.0 & 57.1 & 57.6 & 57.2 & 82.8 & 82.5 & 82.5 & 82.6 & 107.0 & 106.3 & 106.8 & 106.7 & 106.6 & 106.4 & 106.7 & 106.6 \\
\hline Absolute control & - & - & - & 45.6 & - & - & - & 69.2 & - & - & - & 95.7 & - & - & - & 95.1 \\
\hline
\end{tabular}

\begin{tabular}{|c|c|c|c|c|c|c|c|c|}
\hline Source & SEd & $\begin{array}{c}C D \\
(P=0.05)\end{array}$ & SEd & $C D(P=0.05)$ & SEd & $C D(P=0.05)$ & SEd & $C D(P=0.05)$ \\
\hline $\begin{array}{c}\text { Green manure } \\
\text { (G) }\end{array}$ & 1.25 & 2.6 & 1.46 & 3.0 & 1.37 & 2.8 & 1.29 & 2.8 \\
\hline $\begin{array}{c}\text { Vermicompost } \\
\text { (V) }\end{array}$ & 1.08 & $N S$ & 1.26 & $N S$ & 1.19 & $N S$ & 1.12 & $N S$ \\
\hline G $\times$ V & 2.16 & $N S$ & 2.52 & $N S$ & 2.37 & $N S$ & 2.23 & $N S$ \\
\hline Control Vs Rest & 0.77 & 1.6 & 0.89 & 1.9 & 0.84 & 1.7 & 0.79 & 1.6 \\
\hline
\end{tabular}


Table.2 LAI of organically grown rice as influenced by GM/GLM with and without vermicompost

\begin{tabular}{|c|c|c|c|c|c|c|c|c|c|c|c|c|}
\hline \multirow[t]{2}{*}{ Treatments } & \multicolumn{4}{|c|}{ Active tillering } & \multicolumn{4}{|c|}{ Panicle initiation } & \multicolumn{4}{|c|}{ Flowering } \\
\hline & $\mathbf{V}_{0}$ & $\mathbf{V}_{1}$ & $\mathbf{V}_{2}$ & Mean & $\mathbf{V}_{0}$ & $\mathbf{V}_{1}$ & $\mathbf{V}_{2}$ & Mean & $\mathbf{V}_{\mathbf{0}}$ & $\mathbf{V}_{1}$ & $\mathbf{V}_{2}$ & Mean \\
\hline $\mathbf{G}_{1}$-Daincha & 4.1 & .4 .4 & 5.3 & 4.6 & 4.8 & 5.3 & 5.3 & 5.1 & 5.7 & 5.9 & 5.6 & 5.8 \\
\hline $\mathbf{G}_{2}$-Sunnhemp & 3.9 & 3.3 & 3.5 & 3.6 & 4.5 & 4.2 & 4.6 & 4.4 & 4.6 & 4.6 & 5.4 & 4.9 \\
\hline $\mathbf{G}_{3^{-}}$Pungam & 2.8 & 2.7 & 3.5 & 3.0 & 3.5 & 3.6 & 4.2 & 3.8 & 4.2 & 4.2 & 5.2 & 4.5 \\
\hline $\mathbf{G}_{4}$-Gliricidia & 3.7 & 2.9 & 3.0 & 3.2 & 4.4 & 4.0 & 4.2 & 4.2 & 4.7 & 4.2 & 5.0 & 4.6 \\
\hline Treatment mean & 3.7 & 3.3 & 3.8 & 3.6 & 4.3 & 4.3 & 4.6 & 4.4 & 4.8 & 4.7 & 5.3 & 4.9 \\
\hline Absolute control & - & - & - & 1.6 & - & - & - & 2.4 & - & - & - & 2.7 \\
\hline
\end{tabular}

\begin{tabular}{|c|c|c|c|c|c|c|}
\hline Source & SEd & $\boldsymbol{C D}(\boldsymbol{P}=\mathbf{0 . 0 5})$ & SEd & $\boldsymbol{C D}(\boldsymbol{P}=\mathbf{0 . 0 5})$ & SEd & $\boldsymbol{C D}(\boldsymbol{P}=\mathbf{0 . 0 5})$ \\
\hline Green manure (G) & 0.5 & 1.0 & 0.28 & 0.6 & 0.33 \\
\hline Vermicompost (V) & 0.4 & $N S$ & 0.24 & $N S$ & 0.29 \\
\hline G x V & 0.9 & $N S$ & 0.49 & $N S$ & 0.57 \\
\hline Control Vs Rest & 0.3 & 0.6 & 0.17 & 0.4 & 0.20 \\
\hline
\end{tabular}

$V_{2}$-Vermicompost @ 2 tha ${ }^{-1}$ 
Table.3 DMP $\left(\mathrm{kg} \mathrm{ha}^{-1}\right)$ of organically grown rice as influenced by GM/GLM with and without vermicompost

\begin{tabular}{|c|c|c|c|c|c|c|c|c|c|c|c|c|}
\hline \multirow[t]{2}{*}{ Treatments } & \multicolumn{4}{|c|}{ Active tillering } & \multicolumn{4}{|c|}{ Panicle initiation } & \multicolumn{4}{|c|}{ Flowering } \\
\hline & $\mathbf{V}_{0}$ & $V_{1}$ & $\mathbf{V}_{2}$ & Mean & $\mathbf{V}_{0}$ & $\mathbf{V}_{1}$ & $\mathbf{V}_{2}$ & Mean & $\mathbf{V}_{0}$ & $\mathbf{V}_{1}$ & $\mathbf{V}_{2}$ & Mean \\
\hline$G_{1}$-Daincha & 1611 & 1611 & 1583 & 1602 & 5556 & 7028 & 8056 & 6880 & 9167 & 12667 & 13292 & 11709 \\
\hline $\mathbf{G}_{2}$-Sunnhemp & 1056 & 1111 & 1778 & 1315 & 5889 & 6139 & 5500 & 5843 & 9074 & 11111 & 12745 & 10977 \\
\hline $\mathbf{G}_{3}$ - Pungam & 1444 & 1306 & 1417 & 1389 & 4222 & 6822 & 7611 & 6222 & 8222 & 10778 & 10593 & 9864 \\
\hline $\mathbf{G}_{4}$-Gliricidia & 1417 & 1361 & 1417 & 1398 & 6611 & 6361 & 6722 & 6565 & 11296 & 11519 & 11632 & 11482 \\
\hline Treatment mean & 1382 & 1347 & 1417 & 1426 & 5569 & 6590 & 6972 & 6377 & 9440 & 11519 & 12065 & 11008 \\
\hline Absolute control & - & - & - & 1306 & - & - & - & 2361 & - & - & - & 6088 \\
\hline Source & \multicolumn{2}{|c|}{ SEd } & \multicolumn{2}{|c|}{$C D(P=0.05)$} & \multicolumn{2}{|c|}{ SEd } & \multicolumn{2}{|c|}{$C D(P=0.05)$} & \multicolumn{2}{|c|}{ SEd } & \multicolumn{2}{|c|}{$C D(P=0.05)$} \\
\hline Green manure (G) & \multicolumn{2}{|c|}{180.2} & \multicolumn{2}{|c|}{$N S$} & \multicolumn{2}{|c|}{1481.66} & \multicolumn{2}{|c|}{$N S$} & \multicolumn{2}{|c|}{1308.25} & \multicolumn{2}{|c|}{$N S$} \\
\hline Vermicompost (V) & \multicolumn{2}{|c|}{156.1} & \multicolumn{2}{|c|}{$N S$} & \multicolumn{2}{|c|}{1288.16} & \multicolumn{2}{|c|}{$N S$} & \multicolumn{2}{|c|}{1132.98} & \multicolumn{2}{|c|}{$N S$} \\
\hline $\mathbf{G} \times \mathbf{V}$ & \multicolumn{2}{|c|}{312.2} & \multicolumn{2}{|c|}{$N S$} & \multicolumn{2}{|c|}{2566.31} & \multicolumn{2}{|c|}{$N S$} & \multicolumn{2}{|c|}{2265.96} & \multicolumn{2}{|c|}{$N S$} \\
\hline Control Vs Rest & \multicolumn{2}{|c|}{110.4} & \multicolumn{2}{|c|}{$N S$} & \multicolumn{2}{|c|}{907.33} & \multicolumn{2}{|c|}{1881.8} & \multicolumn{2}{|c|}{801.14} & \multicolumn{2}{|c|}{1661.6} \\
\hline
\end{tabular}


Table.4 Yield parameters of organically grown rice as influenced by GM/GLM with and without vermicompost

\begin{tabular}{|c|c|c|c|c|c|c|c|c|c|c|c|c|}
\hline \multirow[t]{2}{*}{ Treatments } & \multicolumn{4}{|c|}{ No. of productive tillers $\mathrm{m}^{-2}$} & \multicolumn{4}{|c|}{ No. of spikelet's panicle ${ }^{-1}$} & \multicolumn{4}{|c|}{ No. of filled grains panicle ${ }^{-1}$} \\
\hline & $\mathbf{V}_{\mathbf{0}}$ & $V_{1}$ & $\mathbf{V}_{2}$ & Mean & $\mathbf{V}_{0}$ & $\mathbf{V}_{1}$ & $\mathbf{V}_{2}$ & Mean & $\mathbf{V}_{0}$ & $\mathbf{V}_{1}$ & $\mathbf{V}_{2}$ & Mean \\
\hline $\mathbf{G}_{1}$-Daincha & 466.2 & 486.2 & 496.2 & 482.9 & 114 & 115 & 114 & 114 & 102.9 & 105.3 & 100.2 & 100.5 \\
\hline $\mathbf{G}_{2}$-Sunnhemp & 422.9 & 402.9 & 436.2 & 419.6 & 108 & 121 & 134 & 121 & 99.3 & 104.0 & 122.5 & 99.3 \\
\hline $\mathbf{G}_{3}$ - Pungam & 386.3 & 396.3 & 419.6 & 399.6 & 113 & 100 & 130 & 114 & 100.6 & 91.5 & 117.0 & 96.3 \\
\hline $\mathbf{G}_{4}$-Gliricidia & 409.6 & 399.6 & 426.2 & 412.9 & 109 & 126 & 130 & 122 & 94.7 & 113.7 & 115.1 & 105.1 \\
\hline Treatment mean & 419.6 & 419.6 & 442.9 & 429.6 & 111 & 114 & 127 & 118 & 99.4 & 106.6 & 113.7 & 100.3 \\
\hline Absolute control & - & - & - & 306.4 & - & - & - & 102 & - & - & - & 93.8 \\
\hline Source & \multicolumn{2}{|c|}{ SEd } & \multicolumn{2}{|c|}{$C D(P=0.05)$} & \multicolumn{2}{|c|}{ SEd } & \multicolumn{2}{|c|}{$C D(P=0.05)$} & \multicolumn{2}{|c|}{ SEd } & \multicolumn{2}{|c|}{$C D(P=0.05)$} \\
\hline Green manure (G) & \multicolumn{2}{|c|}{0.92} & \multicolumn{2}{|c|}{$N S$} & \multicolumn{2}{|c|}{7.17} & \multicolumn{2}{|c|}{$N S$} & \multicolumn{2}{|c|}{6.58} & \multicolumn{2}{|c|}{$N S$} \\
\hline Vermicompost (V) & \multicolumn{2}{|c|}{0.80} & \multicolumn{2}{|c|}{$N S$} & \multicolumn{2}{|c|}{6.21} & \multicolumn{2}{|c|}{12.9} & \multicolumn{2}{|c|}{5.70} & \multicolumn{2}{|c|}{11.4} \\
\hline$G \times V$ & \multicolumn{2}{|c|}{1.60} & \multicolumn{2}{|c|}{$N S$} & \multicolumn{2}{|c|}{12.42} & \multicolumn{2}{|c|}{$N S$} & \multicolumn{2}{|c|}{11.40} & \multicolumn{2}{|c|}{$N S$} \\
\hline Control Vs Rest & \multicolumn{2}{|c|}{0.57} & \multicolumn{2}{|c|}{1.2} & \multicolumn{2}{|c|}{4.39} & \multicolumn{2}{|c|}{$N S$} & \multicolumn{2}{|c|}{3.03} & \multicolumn{2}{|c|}{6.1} \\
\hline
\end{tabular}


Table 5.Grain and straw yield $\left(\mathrm{kg} \mathrm{ha}^{-1}\right)$ and Harvest index of organically grown rice as influenced by GM/GLMwith and without vermicompost

\begin{tabular}{|c|c|c|c|c|c|c|c|c|c|c|c|c|}
\hline \multirow[t]{2}{*}{ Treatments } & \multicolumn{4}{|c|}{ Grain yield $\left(\mathrm{Kg} \mathrm{ha}^{-1}\right)$} & \multicolumn{4}{|c|}{ Straw yield $\left(\mathrm{Kg} \mathrm{ha}^{-1}\right)$} & \multicolumn{4}{|c|}{ Harvest index } \\
\hline & $\mathbf{V}_{0}$ & $\mathbf{V}_{1}$ & $\mathbf{V}_{2}$ & Mean & $\mathbf{V}_{\mathbf{0}}$ & $\mathbf{V}_{1}$ & $\mathbf{V}_{2}$ & Mean & $\mathbf{V}_{\mathbf{0}}$ & $\mathbf{V}_{1}$ & $\mathbf{V}_{2}$ & Mean \\
\hline $\mathbf{G}_{1}$-Daincha & 3776 & 3724 & 3622 & 3707 & 8828 & 9355 & 9703 & 9295 & 0.43 & 0.40 & 0.37 & 0.40 \\
\hline $\mathbf{G}_{2}$-Sunnhemp & 3290 & 3078 & 3242 & 3203 & 9159 & 9089 & 7838 & 8696 & 0.38 & 0.34 & 0.42 & 0.38 \\
\hline $\mathbf{G}_{3}$ - Pungam & 2594 & 3138 & 3354 & 3029 & 8119 & 8493 & 8174 & 8262 & 0.32 & 0.37 & 0.41 & 0.39 \\
\hline $\mathbf{G}_{4}$-Gliricidia & 2837 & 3028 & 3265 & 3043 & 8116 & 7154 & 8633 & 7968 & 0.36 & 0.43 & 0.39 & 0.39 \\
\hline Treatment mean & 3124 & 3242 & 3371 & 3246 & 8556 & 8523 & 8587 & 8555 & 0.37 & 0.39 & 0.40 & 0.38 \\
\hline Absolute control & - & - & - & 2450 & - & - & - & 6560 & - & - & - & 0.32 \\
\hline
\end{tabular}

\begin{tabular}{|c|c|c|c|c|c|c|}
\hline Source & SEd & $\boldsymbol{C D}(\boldsymbol{P}=\mathbf{0 . 0 5})$ & SEd & $\boldsymbol{C D}(\boldsymbol{P}=\mathbf{0 . 0 5})$ & SEd & $\boldsymbol{C D}(\boldsymbol{P}=\mathbf{0 . 0 5})$ \\
\hline Green manure (G) & 171.4 & 356 & 683.1 & $N S$ & 0.021 \\
\hline Vermicompost (V) & 148.5 & $N S$ & 591.6 & $N S$ & 0.021 \\
\hline G x V & 296.9 & $N S$ & 1183.1 & $N S$ & 0.043 \\
\hline Control Vs Rest & 125.0 & 218 & 418.3 & 868 & 0.012 \\
\hline
\end{tabular}

$V_{0}-$ No Vermicompost

$V_{l}$-Vermicompost @ $1 \mathrm{th} \mathrm{a}^{-1}$,

$V_{2}-$ Vermicompost @ 2 tha $a^{-1}$ 
Fig.1

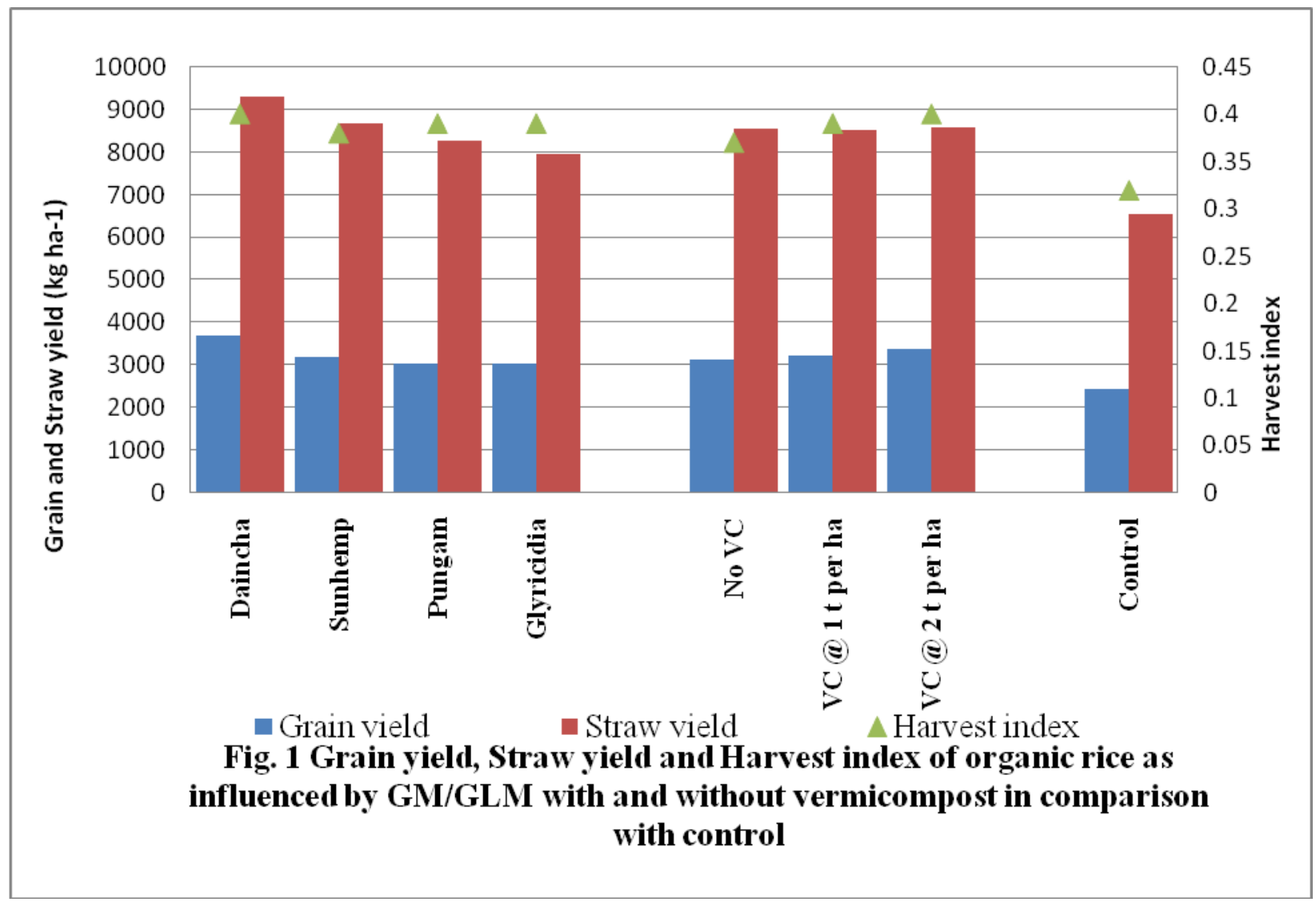

The post era of green revolution has led to environmental pollution due to excessive use of agrochemicals and fertilizers and thus threatened the fragile ecosystem. Organic agriculture is the key to a sound development which avoids use of harmful chemicals and use of natural resources such as organic matter, minerals and microbes to the environment clean, ecological balance and to provide stability to the production without polluting the soil, water and air.

\section{Acknowledgements}

I take this opportunity to express deep due sense of gratitude to the chairperson of my Advisory committee, Dr. L. ARUNA, Associate Professor, Department of Soil science and Agricultural Chemistry, PAJANCOA \& RI. It is with great respect and devotion I place on record, my deep sense of gratitude and indebtedness to my advisory committee members Dr. K. OMAR HATTAB, Professor, Department of Soil Science and Agricultural Chemistry and Dr. AL. NARAYANAN, Professor and Head, Department of Agronomy. PAJANCOA \& RI.

\section{References}

Ali. M., and Narciso. J. H. 1993. The perception and reality of GM use in rice: an economic evaluation, IRRI Social Science Division Paper Series. The International Rice Research Institute, Los Bafios, p 42

Amanullah, H. 2016. Influence of organic and inorganic nitrogen on grain yield and yield components of hybrid rice in Northwestern Pakistan. Rice Sci, 
23(6), pp.326-333.

Ladha, S. K., De Datta and Ottow. J. C. G. 1995. Effect of NPK on growth and nitrogen fixation of $S$. rostrataas green manure for low land rice. Plant and Soil, 132: $149-158$.

Lourduraj, A.C. 2005.Effect of organic manures and panchagavya spray on growth attributes and yield of rice (Oryza sativa L.). Environment \& Agriculture, p.27.

Mohandas, S., V. Paramasivam and Sakthivel. N. 2008. Phosphorus and zinc enriched organics for enhancing the yield of transplanted rice in new Cauvery delta, Tamil Nadu. J. Ecobiol, 23(3), pp.7376.

Oyekanmi, A. A., C. A. Okeleye and Okonji. C. J. 2008. On-farm evaluation of rainfed lowland rice varieties at
Olokose Village, Odeda, Ogun State, Nigeria. J. Agron, 7(2), pp.192-196.

Rangaswamy, R. 2016. A Textbook of Agricultural Statistics. Second edition. Published by New Age International, New Delhi.

Roy, D. K. and Singh. B. P. 2006. Effect of level and time of nitrogen application with and with out vermicompost on yield, yield attributes and quality of malt barley (Hordeum vulgare). Indian J. Agron., 51(1): 40-42.

Sharma, R. S, V. Gupta and Vishwakarma. S. K. 2006. Long-term effect of integrated nutrient management on yield sustainability and soil fertility of rice (Oryza sativa)-wheat (Triticum aestivum) cropping system. Indian Journal of Agronomy, 51(3), pp.160164.

\section{How to cite this article:}

Sathiyabama, N., L. Aruna, K.Illakia, C. Dhayanithi, V. S. V. G. Naresh, R. Jayaraghavi and Mageshen, V. R. 2021. Effect of Organic Manure on Growth and Yield of Transplanted Rice (Oryza sativa L.) under Coastal Cauvery Deltaic Region. Int.J.Curr.Microbiol.App.Sci. 10(06): 715-728. doi: https://doi.org/10.20546/ijcmas.2021.1006.079 